\title{
Teaching NeuroImages: Scleral thickening and optic disc edema from glycosaminoglycan deposition in Hunter syndrome
}

Meagan D. Seay, DO, Heather Lau, MD, and Steven L. Galetta, MD

Neurology ${ }^{\circledR}$ 2019;92:e1532-e1533. doi:10.1212/WNL.0000000000007183
Correspondence

Dr. Seay

Meagan.Seay@hsc.utah.edu

Figure Fundus photographs and MRI
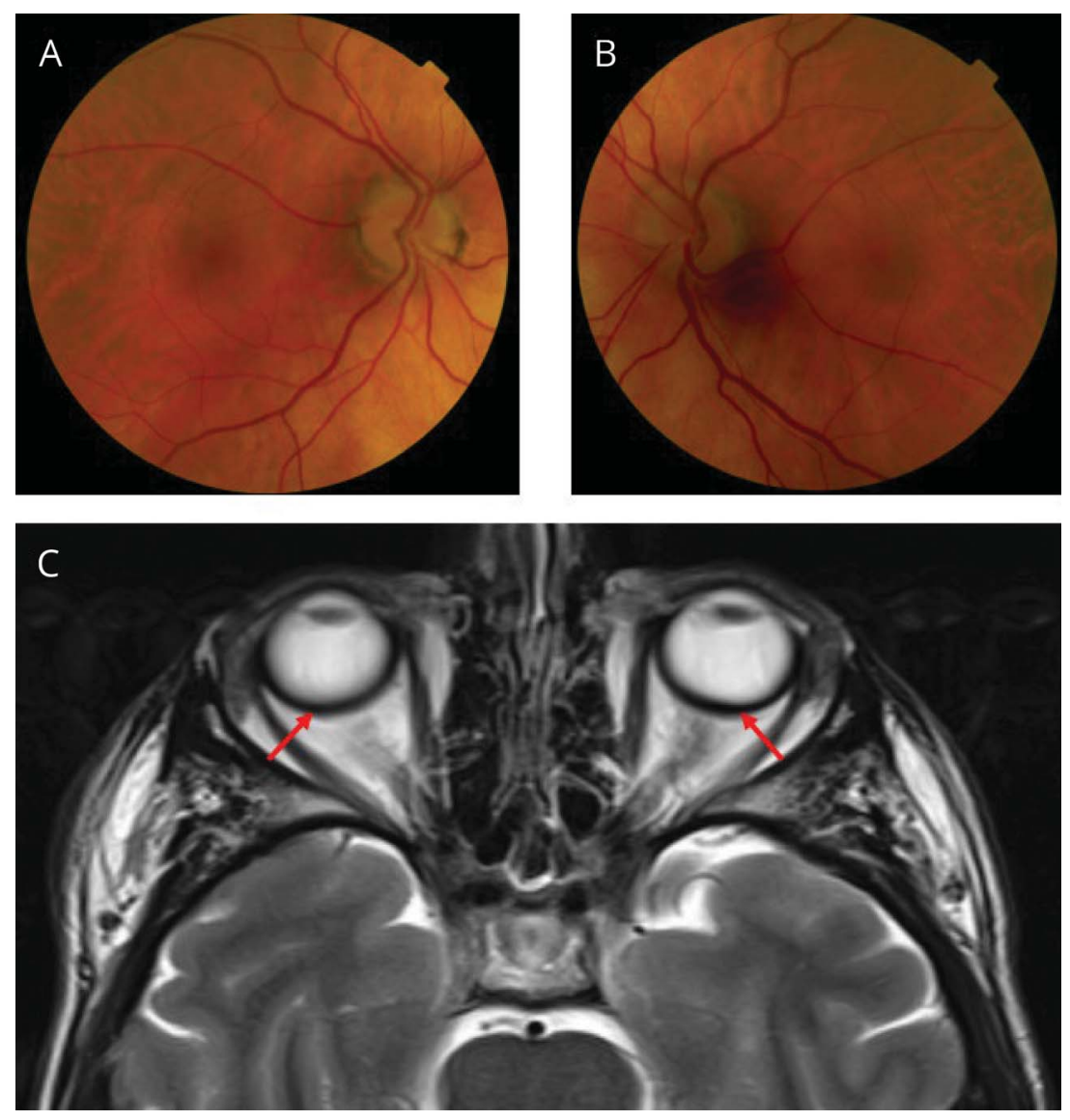

Fundus photographs demonstrate waxy pallor of the right optic nerve (A) and optic disc edema of the left eye (B). (C) Axial T2-weighted MRI with symmetric hypointense signal circumferentially along the globes most notable along the posterior margins indicates thickened sclera from glycosaminoglycan deposition.
A 43-year-old man with a history of Hunter syndrome presented to the neuro-ophthalmology clinic with decreased peripheral vision. Computerized visual field testing revealed bilateral ring scotomas. The right optic disc was flat and there was left optic disc edema. Optical coherence tomography revealed disc edema of the left nerve, inner microcystic changes in the nasal fovea of the left eye, and parafoveal atrophy of the outer retinal layers in both eyes. MRI demonstrated posterior ocular globe thickening likely secondary to glycosaminoglycan deposition in the sclera (figure), known to occur in Hunter syndrome. ${ }^{1}$ The mechanism of the optic disc edema in our patient could have been from compression of the optic nerve at the scleral opening.

\section{MORE ONLINE}

\section{$\rightarrow$ Teaching slides}

links.lww.com/WNL/

A 845 


\section{Author contributions}

Meagan D. Seay: drafting/revising the manuscript, data acquisition, study concept or design, analysis or interpretation of data, accepts responsibility for conduct of research and final approval. Heather Lau: drafting/revising the manuscript, data acquisition, study concept or design, analysis or interpretation of data, accepts responsibility for conduct of research and final approval, acquisition of data. Steven L. Galetta: drafting/ revising the manuscript, accepts responsibility for conduct of research and final approval.

\section{Study funding}

No targeted funding reported.

\section{Disclosure}

The authors report no disclosures relevant to the manuscript. Go to Neurology.org/ $\mathrm{N}$ for full disclosures.

\section{Reference}

1. Schumacher RG, Brzezinska R, Schulze-Frenking G, Pitz S. Sonographic ocular findings in patients with mucopolysaccharidoses I, II and VI. Pediatr Radiol 2008;38: 543-550. 


\section{Neurology}

\section{Teaching NeuroImages: Scleral thickening and optic disc edema from glycosaminoglycan deposition in Hunter syndrome \\ Meagan D. Seay, Heather Lau and Steven L. Galetta \\ Neurology 2019;92;e1532-e1533 \\ DOI 10.1212/WNL.0000000000007183}

\section{This information is current as of March 25, 2019}

\section{Updated Information \&} Services

References

Subspecialty Collections

Permissions \& Licensing

\section{Reprints}

including high resolution figures, can be found at: http://n.neurology.org/content/92/13/e1532.full

This article cites 1 articles, 0 of which you can access for free at: http://n.neurology.org/content/92/13/e1532.full\#ref-list-1

This article, along with others on similar topics, appears in the following collection(s):

\section{All Genetics}

http://n.neurology.org/cgi/collection/all_genetics

All Medical/Systemic disease

http://n.neurology.org/cgi/collection/all_medical_systemic_disease Optic nerve

http://n.neurology.org/cgi/collection/optic_nerve

Information about reproducing this article in parts (figures,tables) or in its entirety can be found online at:

http://www.neurology.org/about/about_the_journal\#permissions

Information about ordering reprints can be found online:

http://n.neurology.org/subscribers/advertise

Neurology ${ }^{\circledR}$ is the official journal of the American Academy of Neurology. Published continuously since 1951, it is now a weekly with 48 issues per year. Copyright @ 2019 American Academy of Neurology. All rights reserved. Print ISSN: 0028-3878. Online ISSN: 1526-632X.

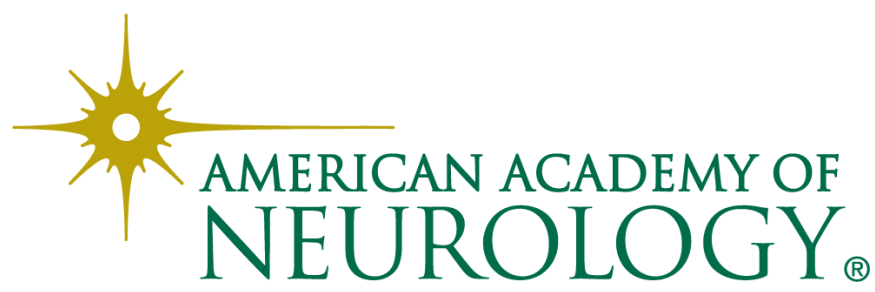

